\title{
Age of Mammuthus trogontherii from Kostolac, Serbia, and the entry of megaherbivores into Europe during the Late Matuyama climate revolution
}

\author{
Giovanni Muttoni a,*, Giancarlo Scardia ${ }^{\mathrm{b}}$, Vesna Dimitrijević ${ }^{\mathrm{c}}$, Dennis V. Kent ${ }^{\mathrm{d}, \mathrm{e}}$, Edoardo Monesi ${ }^{\mathrm{a}}$, \\ Nemanja Mrdjić ${ }^{\mathrm{f}}$, Miomir Korać ${ }^{\mathrm{f}}$ \\ a Dipartimento di Scienze della Terra 'Ardito Desio', Università degli Studi di Milano, via Mangiagalli 34, I-20133 Milan, Italy \\ b Instituto de Geociências e Ciências Exatas, Universidade Estadual Paulista, Rio Claro, SP 13506-900, Brazil \\ c Laboratory for Bioarchaeology, Department of Archaeology, Faculty of Philosophy, University of Belgrade, Čika Ljubina 18-20, Belgrade, Serbia \\ ' Earth E' Planetary Sciences, Rutgers University, Piscataway, NJ 08854, USA \\ e Lamont-Doherty Earth Observatory of Columbia University, Palisades, NY 10964, USA \\ ${ }^{\mathrm{f}}$ Archaeological Institute, Serbian Academy of Sciences and Arts, Knez Mihajlova 35, Belgrade, Serbia
}

\section{A R T I C L E I N F O}

Article history:

Received 11 February 2015

Available online 23 October 2015

\section{Keywords:}

Mammuthus trogontherii

Serbia

Magnetostratigraphy

Late Matuyama

Pleistocene

\begin{abstract}
A B S T R A C T
At the Drmno open-pit coal mine near Kostolac in Serbia, a nearly complete skeleton of Mammuthus trogontherii (nicknamed Vika) was discovered in a fluvial deposit overlain by a loess-paleosol sequence where a second paleontological level named Nosak with remains of $M$. trogontherii was found. We studied the magnetostratigraphy of the Kostolac sedimentary sequence and found that the Vika layer dates to $~ 0.8 \mathrm{Ma}$, shortly before the BrunhesMatuyama boundary. In addition, according to our age model and previously reported optically stimulated luminescence and electron spin resonance dates, the Nosak fossils have an estimated age of $0.19 \mathrm{Ma}$ and lived during the earliest part of Marine Isotope Stage 6. It appears therefore that at Kostolac, M. trogontherii is preserved both at its earliest occurrence at $\sim 0.8 \mathrm{Ma}$ and close to its latest occurrence at $0.19 \mathrm{Ma}$, and may well have been present in between, albeit not yet found. We speculate that megaherbivores such as M. trogontherii entered Europe along a conjunct Danube-Po River migration conduit connecting western Asia-Levant with central-southern Europe where vast and exploitable ecosystems, particularly suited for steppe- or savanna-adapted megaherbivores from Asia and Africa, developed during the late early Pleistocene climate revolution at around 0.8 Ma.
\end{abstract}

(c) 2015 University of Washington. Published by Elsevier Inc. All rights reserved.

\section{Introduction}

The Drmno open-pit coal mine near Kostolac in Serbia (Fig. 1A, B) yielded a nearly complete and in situ skeleton of Mammuthus trogontherii, informally named Vika (Lister et al., 2012), from a fluvial sand interval (Fig. 2A) sealed by a thick loess-paleosol succession (Fig. 2B), itself containing a second paleontological layer, termed Nosak, with fossils of the same mammoth species (Marković et al., 2014; Dimitrijević et al., 2015).

M. trogontherii is an Asian immigrant that is commonly regarded to have reached the eastern fringes of Europe at $\sim 1.0 \mathrm{Ma}$ and central Europe just before the 0.78 Ma Brunhes-Matuyama boundary (Lister et al., 2005; Kahlke, 2014; see also discussion below). Muttoni et al. (2014) recently hypothesized that large mammals and hominins, interlinked in a common food web, expanded into Europe along a conjunct Danube-Po Gateway during the late Early Pleistocene (Late

\footnotetext{
* Corresponding author.

E-mail address: giovanni.muttoni1@unimi.it (G. Muttoni).
}

Matuyama) climate revolution (hereafter referred to as EPR) broadly starting at $\sim 0.9 \mathrm{Ma}$ (Muttoni et al., 2014). The level with the first occurrence of $M$. trogontherii at Kostolac might therefore represent a stratigraphic expression of the EPR in the Danube Valley (similar to the ' $R$ surface' in the Po Valley dated at $\sim 0.9 \mathrm{Ma}$; Muttoni et al., 2003; Scardia et al., 2006) along which paleontological and anthropological surveys in search for Asian and African mammal immigrants, including early hominins, could productively focus (Muttoni et al., 2014).

In this paper, we report the magnetostratigraphy of the Kostolac sedimentary record and find that the Vika layer dates to the Late Matuyama, shortly before the Brunhes-Matuyama boundary (0.78 Ma; time scale of Lourens et al., 2004). With a new estimated age of $\sim 0.8 \mathrm{Ma}$, Vika, which was until recently only broadly constrained between 1.0 and $0.4 \mathrm{Ma}$ (Lister et al., 2012), now represents one of the best-dated and oldest fossils of $M$. trogontherii in Europe. In addition, the Nosak M. trogontherii fossils, with an estimated age of $0.19 \mathrm{Ma}$ (Dimitrijević et al., 2015), appear to be among the youngest of this taxon in Europe (Lister and Sher, 2001). Hence, it seems that Kostolac represents a remarkable paleontological site where $M$. trogontherii is preserved at the limits of its temporal range. 


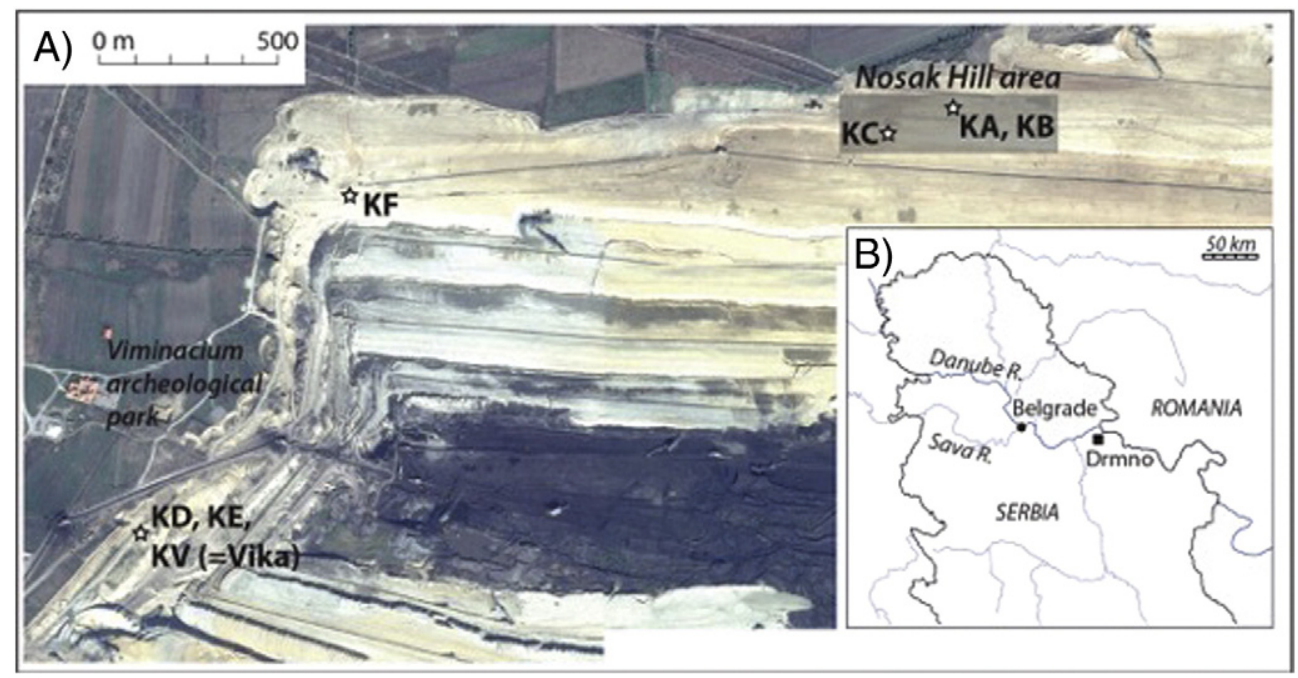

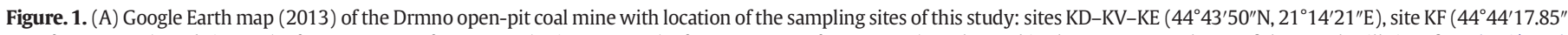

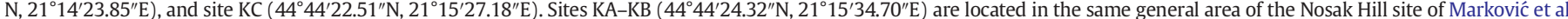

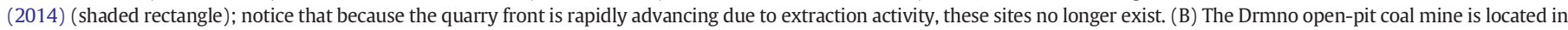
Serbia, $90 \mathrm{~km}$ southeast of Belgrade near the town of Kostolac.

\section{Geological settings}

The stratigraphy of the Kostolac basin is made available by extensive coal mining excavations. The strata consist of Pontian (= latest Miocene Paratethys stage, coeval with the Messinian) lacustrine deposits and deltaic sands, unconformably overlain by Pleistocene deposits divided into a lower complex of fluvial sediments and an upper complex of loess-paleosols (Lister et al., 2012; Marković et al., 2014; Dimitrijević et al., 2015).

The Pleistocene lower complex is composed of gravel, cross-bedded sands, and organic-rich silt interpreted as fluvial-channel deposits, interbedded with fine-grained, massive or laminated, organic-rich sediments interpreted as overbank deposits. The skeleton of Vika was unearthed in 2009 in the southwestern part of the open-pit mine (Fig. 1A, site KV) while a large excavation digger was removing the sediment overburden to access the underlying coal beds. The paleontological layer is located at the base of the lower complex at an elevation (above standard sea level) of approximately $58 \mathrm{~m}$, about $5 \mathrm{~m}$ below the base of the loess-paleosol sequence (Lister et al., 2012) (Fig. 3, site KV). The digger destroyed the left side of the skull and damaged the bones of the left front leg. All other elements of the skeleton are present, including preserved counterparts on the right side. Vika is the first largely complete and anatomically articulated skeleton of this species found in the Balkan Peninsula and the Mediterranean area. Moreover, the skeleton is preserved in the animal's death posture, which is an exceptional taphonomic situation for any fossil specimen (Lister et al., 2012).

The upper complex comprises a succession of loess layers and paleosols. At the Nosak Hill site (Fig. 1A), Marković et al. (2014) reported the lithology and magnetic susceptibility of a 25.4-m-thick loesspaleosol sequence from $72.3 \mathrm{~m}$ to $97.7 \mathrm{~m}$ in elevation. Starting at the top, soil S0 is underlain by extended loess L1, then by soil S1, loess L2,

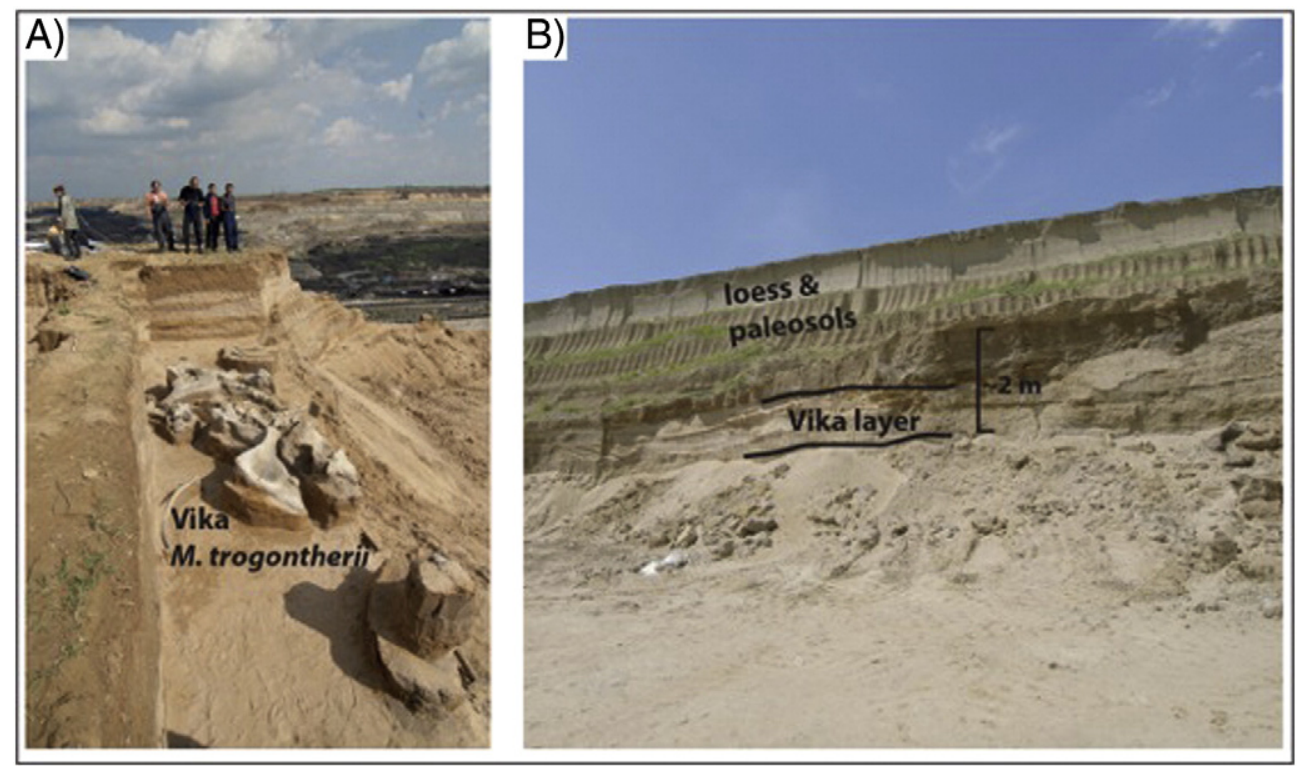

Figure. 2. The skeleton of Vika (Mammuthus trogontherii) unearthed in 2009 (A) in fluvial layers overlain by a loess-paleosol sequence (B). 


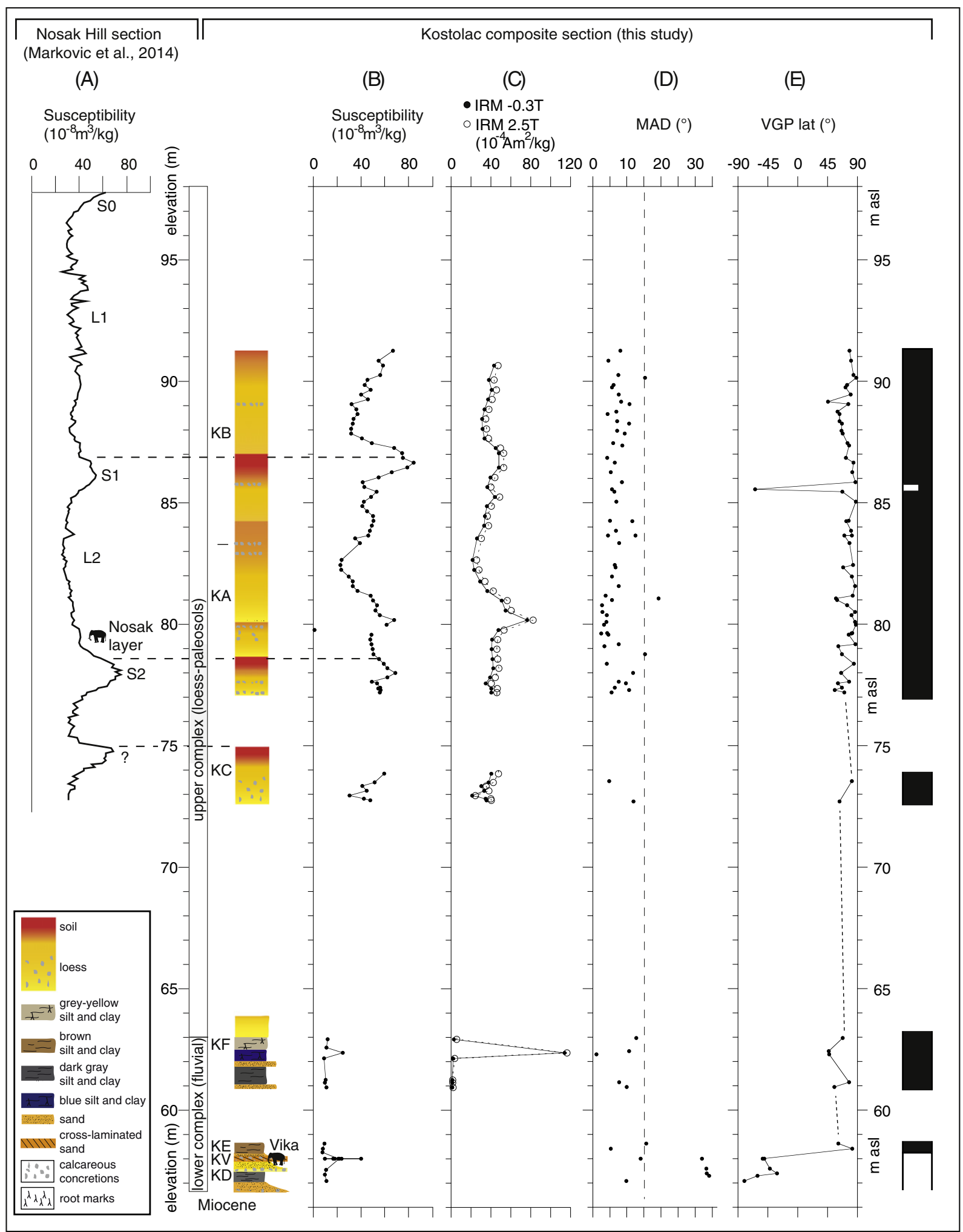

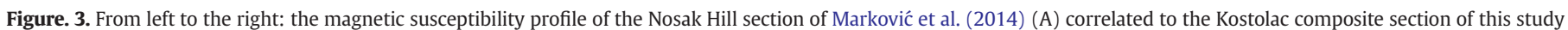

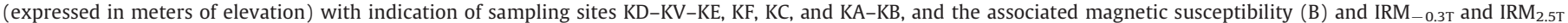

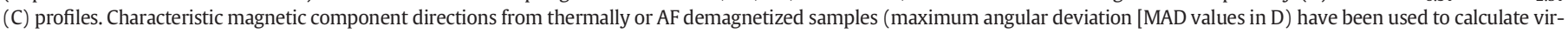
tual geomagnetic pole (VGP) latitudes (E) and magnetic polarity for the Kostolac composite section (black is normal polarity, white is reverse polarity). See text for discussion.

and, finally, a basal couplet of soils labeled S2 and '?' ( soil and loess nomenclature after Marković et al., 2014) (Fig. 3A). This sequence was attributed by Marković et al. (2014) to the last glacial-interglacial cycles of Marine Isotope Stage (MIS) 1 to MIS 7, using magnetic susceptibility correlations with sections from the literature and two preliminary post-
IR infrared stimulated luminescence (post-IR IRSL) dates indicating minimum ages of $0.15 \mathrm{Ma}$ for the base of L2 (Marković et al., 2014). This latter attribution has been recently confirmed by a new electronic spin resonance (ESR) date of $0.192 \pm 0.005 \mathrm{Ma}$ on a mammoth molar from the Nosak fossil layer located at the base of loess L2 (Dimitrijević 
et al., 2015; see also below). In addition, the couplet of cambisols S2 and '?' located below L2, and characterized by a well-developed B horizon, displays similarities with the Basaharc double soil complex at Paks, Hungary (Sartori et al., 1999), dated with the post-IR IRSL method to MIS 7 (Thiel et al., 2014). Therefore, key loess interval L2 should correspond to MIS 6 (see also age model below).

The Nosak fossil layer lies at $\sim 79-80 \mathrm{~m}$ in elevation and $\sim 20 \mathrm{~m}$ above the Vika layer, at the base of loess L2 (Fig. 3A). Skeletal remains, scattered over an area up to $10 \mathrm{~m}$ wide and $130 \mathrm{~m}$ long within this layer, were excavated in 2012; preliminary analyses indicate remains from at least four mammoths, a horse, and a cervid that, according to recent ESR analyses, lived $0.192 \pm 0.005 \mathrm{Ma}$ ago during the earliest part of MIS 6 (Dimitrijević et al., 2015).

Sites sampled for paleomagnetic analyses are (Fig. 1A): KD-KV-KE, consisting of three stratigraphically superposed sites encompassing the Vika layer (KV), site KF located $1 \mathrm{~km}$ to the NE of sites KD-KV-KE, site $K C$ located $1.4 \mathrm{~km}$ to the ENE of site $\mathrm{KF}$, and stratigraphically superposed sites KA-KB located $0.2 \mathrm{~km}$ to the ENE of site KC. Sites KC and KA$\mathrm{KB}$ are in the same general area of the Nosak Hill site of Marković et al. (2014), which, however, no longer exists due to coal extraction activity (Fig. 1A). Altimetric leveling and visual lateral tracing of marker beds were used to construct a common stratigraphic scheme of the sites in a Kostolac composite section expressed in meters of elevation (Fig. 3).

\section{Paleomagnetism and magnetostratigraphy}

We conducted paleomagnetic analyses on a total of 152 stratigraphically superposed samples from the Kostolac composite section. The sample set consisted of 55 standard $10-\mathrm{cm}^{3}$ core samples that were drilled in the field with a cordless drill and oriented with a magnetic compass, and an additional 97 oriented samples that were obtained by inserting $10-\mathrm{cm}^{3}$ plastic boxes into outcrop sections. Thermal demagnetization was applied to the all 55 core samples, and alternating field ( $\mathrm{AF}$ ) demagnetization to 49 of the 97 plastic box samples, with the natural remanent magnetization (NRM) measured after each step on a 2G-Enterprises DC squid cryogenic magnetometer in a magnetically shielded room. Standard least-square analysis was used to calculate component directions from selected segments of vector end-point diagrams. Rock-magnetic properties were studied on 13 plastic box samples by means of isothermal remanent magnetization (IRM) backfield acquisition curves. Forty-eight plastic box samples were also given an IRM of $2.5 \mathrm{~T}$ in one direction ( IRM $_{2.5 \mathrm{~T}}=$ saturation IRM or SIRM) and of $0.3 \mathrm{~T}$ in the opposite direction $\left(\mathrm{IRM}_{-0.3 \mathrm{~T}}\right.$ ). The initial magnetic susceptibility was measured on the 97 plastic box samples with an Agico Kappabridge KLY-2. IRM and susceptibility values were normalized by weight. All experiments were conducted at the Alpine Paleomagnetic Laboratory at Peveragno (Italy).

Samples from fluvial sediments below the loess-paleosol sequence ( sites KD-KV-KE, and KF) are characterized by IRM acquisition curves that approach saturation by $\sim 300 \mathrm{mT}$, but then continue to gently climb up to the highest applied fields of $2500 \mathrm{mT}$ (Fig. 4); this behavior is interpreted as due to the presence of low coercivity magnetite in association with high coercivity hematite. Samples from the loesspaleosol sequence (sites $\mathrm{KC}$ and $\mathrm{KA}-\mathrm{KB}$ ) are dominated by a magnetic phase that shows tendency to saturate by $\sim 300 \mathrm{mT}$ (Fig. 4) interpreted as magnetite. Maximum unblocking temperatures of the natural remanent magnetization (NRM) on the order of $575^{\circ} \mathrm{C}$ confirm the presence of magnetite as main carrier of the magnetic remanence in the loesspaleosol sequence (see also below).

The initial susceptibility, normalized by sample weight, shows low values less than about $20 \times 10^{-8} \mathrm{~m}^{3} / \mathrm{kg}$ in the lower fluvial complex and higher values in the upper loess-paleosol complex, where peak values of $\sim 90 \times 10^{-8} \mathrm{~m}^{3} / \mathrm{kg}$ are attained in the more developed paleosol intervals (Fig. 3B). The susceptibility profile coupled with elevation data were used to correlate our Kostolac composite section to the Nosak Hill section of Marković et al. (2014). High susceptibility values of Nosak Hill soil S1 were correlated to high susceptibility values of the soil at $86.5 \mathrm{~m}$ of the Kostolac composite section (Fig. 3A, B). The double cambisol pedocomplex in the lower part of the Nosak Hill section, termed S2 and '?' in Marković et al. (2014), is tentatively correlated to similar rubified paleosols with clay-rich B horizons located at 78.5 and $74.5 \mathrm{~m}$ of the Kostolac composite section (Fig. 3A, B). According to this correlation, the uppermost Nosak Hill soil S0 lies $\sim 7 \mathrm{~m}$ above the top of the Kostolac composite section.

The $I_{R M} M_{2.5 T}$ and $I_{R M} M_{-0.3 T}$ values are similar (Fig. $3 C$ ) and tend to mimic the susceptibility trend with highest values in the pedogenized parts of the sequence related to higher concentrations of ferromagnetic minerals. The resulting 'S'-ratio, calculated as IRM ${ }_{-0.3 T} / \mathrm{SIRM}$ (not shown), is generally comprised between 0.8 and 0.9 , except for the lowermost samples from the fluvial unit with S-ratios of 0.5-0.7.

Characteristic remanent magnetization (ChRM) component directions have been isolated in 70 samples with progressive demagnetization from room temperature or null up to a maximum of $\sim 575^{\circ} \mathrm{C}$ or $\sim 100 \mathrm{mT}$ alternating field (AF)(Fig. 5A) and are characterized by maximum angular deviation (MAD) values of generally less than $15^{\circ}$ except for the lowermost samples with MADs of $\sim 30-35^{\circ}$ (Fig. 3D). These ChRM directions have been found to be oriented either north and down (positive inclination) or south and up (negative inclination) (Fig. 5A) with an overall mean in common polarity of Dec. $=3.3^{\circ} \mathrm{E}$, Inc. $=52.9^{\circ}$ (Fig. $5 \mathrm{~B}$ ). The latitude of the virtual geomagnetic pole (VGP) derived from each ChRM direction relative to the mean paleomagnetic (north) pole axis was used for interpreting polarity stratigraphy (Fig. 3E). VGP latitudes approaching $+90^{\circ}$ or $-90^{\circ}$ are interpreted as recording normal or reverse polarity, respectively. The fluvial layers of the lower complex, including the layer hosting the Vika fossil, are characterized by relatively poorly defined reverse polarity. The overlying loess-paleosol sequence of the upper complex exhibits normal polarity. The reverse-normal polarity transition is placed at $\sim 58.3 \mathrm{~m}$, immediately above the Vika layer. A one-sample-based reverse polarity excursion is observed at level $\sim 85.5 \mathrm{~m}$ (Fig. 3E).

The main polarity reversal at $\sim 58.3 \mathrm{~m}$ most probably represents a record of the Brunhes-Matuyama boundary ( $0.78 \mathrm{Ma})$, which would imply substantial stratigraphic continuity throughout the studied sequence. Alternatively, it could represent a record of an older polarity reversal, such as the Jaramillo-Matuyama boundary (1.07 Ma), which would imply a hiatus of about 200 ka between the lower fluvial and the upper loess-paleosol sequences. Unconformities with lack of deposition may arise from reduction of accommodation space due to uplift, as in the case of the northern Po River basin in northern Italy, which, after a prolonged period of regional subsidence, experienced isostatic uplift during the middle Pleistocene becoming an area of bypass for sediments (Scardia et al., 2012). There is, however, no evidence to our knowledge of uplift of the Kostolac basin during the late early Pleistocene that could trigger the formation of such long-lasting unconformities. The presence of an erosional hiatus is even less viable considering that no paleosol has been observed at the top of the fluvial succession. Besides, loess deposition is a low-energy settling process hardly capable of eroding underlying sediments.

In conclusion, we infer that the observed polarity reversal represents a record of the Brunhes-Matuyama boundary (0.78 Ma) preserved within a substantially continuous stratigraphic sequence. This preferred interpretation is in substantial agreement with previous chronologies that place the onset of loess deposition in the Danube valley shortly below the Brunhes-Matuyama boundary (Sartori et al., 1999; Marković et al., 2011; Fitzsimmons et al., 2012; Marković et al., 2012, 2014).

\section{Age model of sedimentation}

Using magnetostratigraphy coupled with correlation of the extended loess-paleosol sequence of China (Ding et al., 2005) and Europe (Marković et al., 2011; Fitzsimmons et al., 2012; Marković et al., 2012 


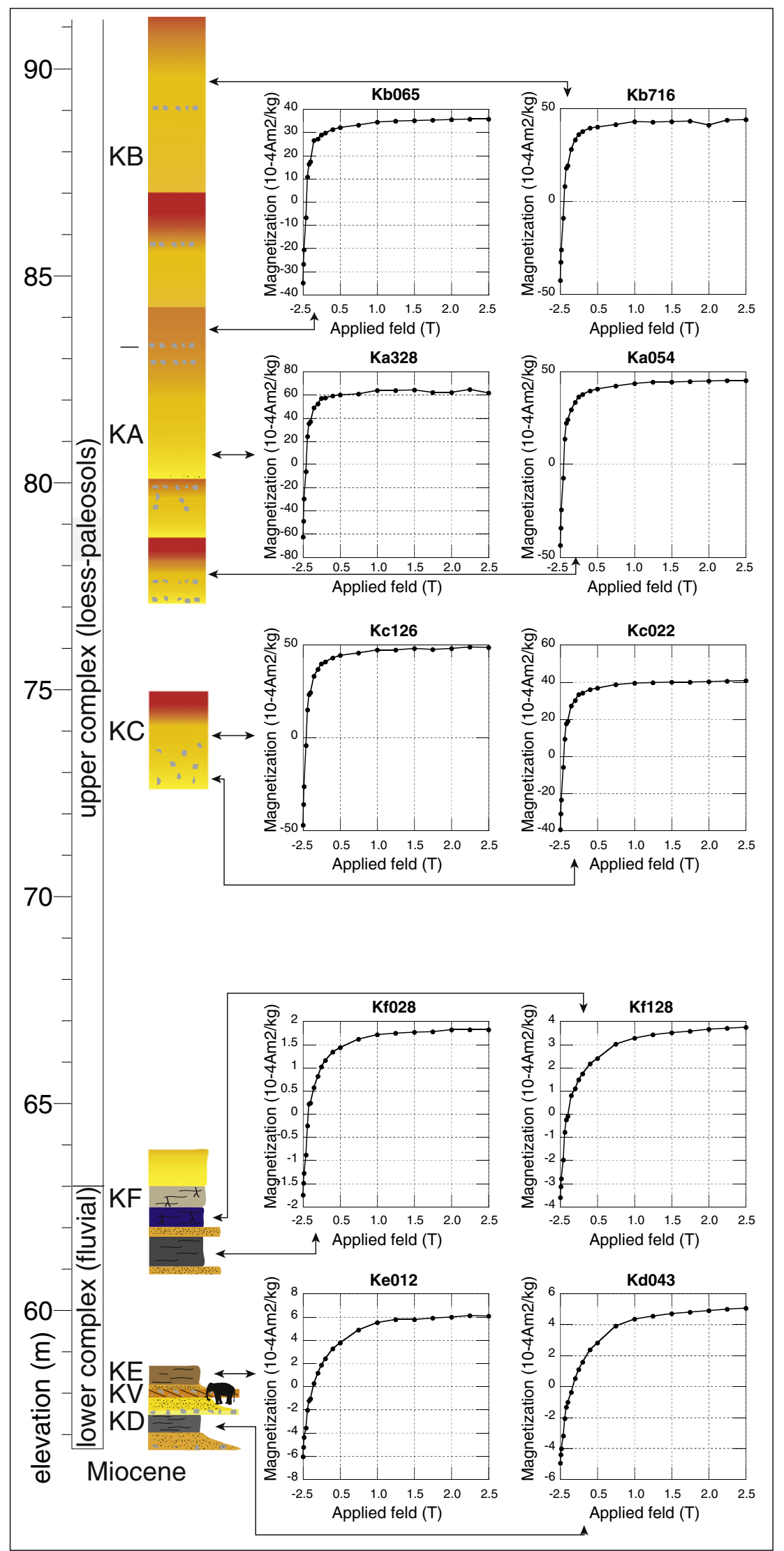

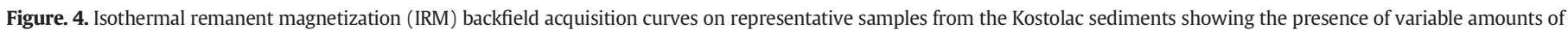
low- and high-coercivity magnetic components interpreted as magnetite and hematite, respectively. See text for discussion. 


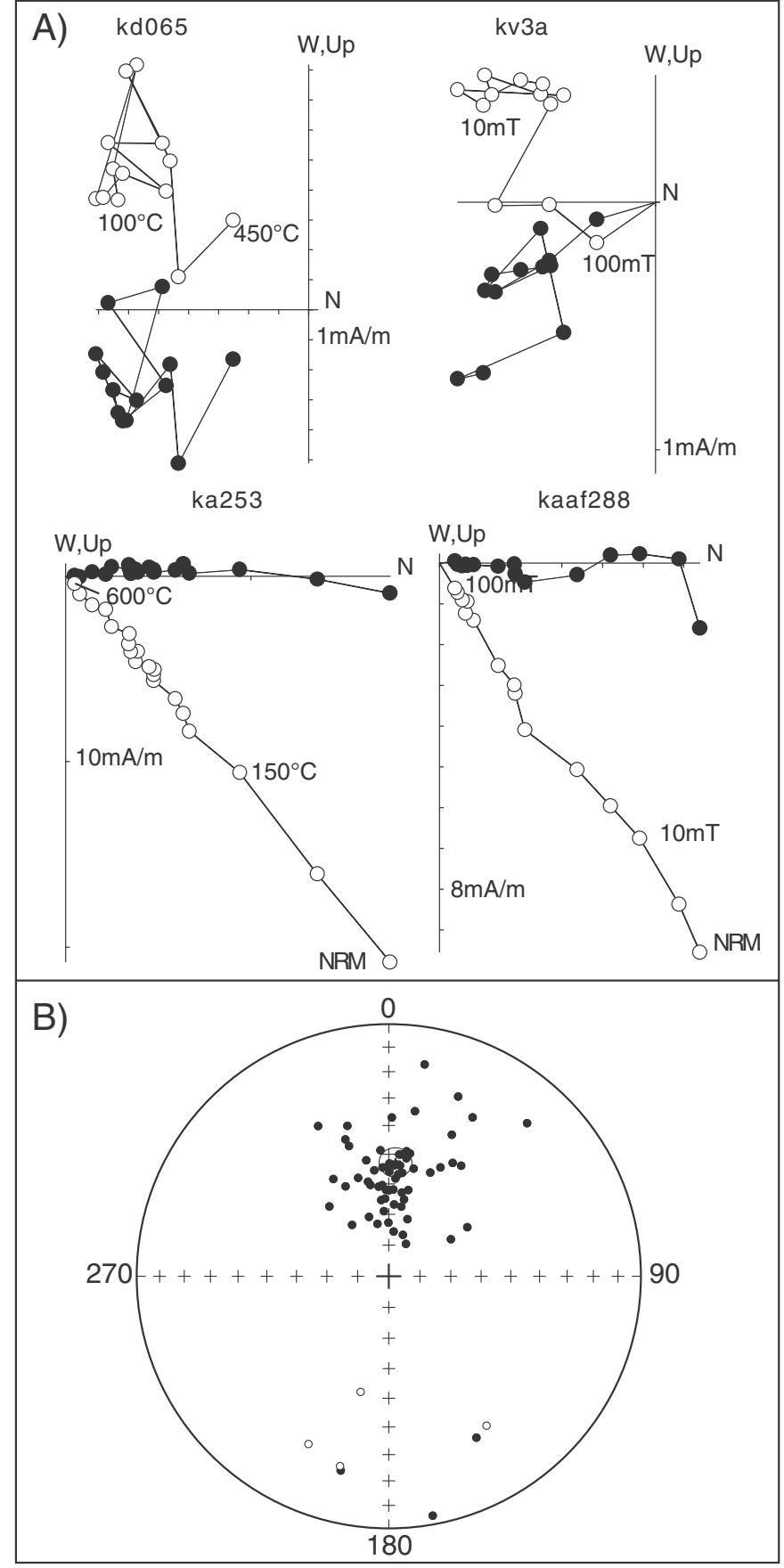

Figure. 5. (A) Vector end-point demagnetization diagrams of representative samples displaying characteristic magnetic component directions of reverse (Kd065, Kv3a) and normal (Ka253, Kaaf288) magnetic polarity. Closed symbols are projections onto the horizontal plane and open symbols onto the vertical plane. Demagnetization temperatures are expressed in ${ }^{\circ} \mathrm{C}$ or $\mathrm{mT}$. (B) Equal-area projection of the characteristic remanent magnetization component directions and associated Fisher statistics mean direction (Dec. = $3.3^{\circ} \mathrm{E}$, Inc. $=52.9^{\circ}, \mathrm{k}=13, \alpha 95=4.9^{\circ}, \mathrm{N}=70$ ); closed (open) symbols represent down-pointing (up-pointing) directions.

2014) with the standard benthic $\delta^{18} \mathrm{O}$ record (Lisiecki and Raymo, 2005), an age model of sedimentation has been constructed for the Kostolac composite section that takes into account the following tie points, from top to bottom (Fig. 6):

1) Soil S0 centered at $\sim 98 \mathrm{~m}$ is attributed to MIS 1.

2) Soil S1 centered at $\sim 86.5 \mathrm{~m}$ is attributed to MIS 5e; the reverse polarity excursion observed at $\sim 85.5 \mathrm{~m}$ could represent a partial record of the Blake event, dated to $0.115-0.120 \mathrm{Ma}$ (Singer, 2014) and falling in the late Eemian (MIS 5e; Thouveny et al., 2008).

3) The Nosak level with $M$. trogontherii at the base of loess L2 is dated to $0.192 \pm 0.005 \mathrm{Ma}$ in the earliest part of MIS 6 according to (preliminary) ESR dating (Dimitrijević et al., 2015).

4) The cambisol couplets S2 and '?' centered at $\sim 78.5 \mathrm{~m}$ and $\sim 74.5 \mathrm{~m}$ are attributed to MIS 7a and MIS7e, respectively.

5) The Brunhes-Matuyama boundary at $0.78 \mathrm{Ma}$ occurs at $\sim 58.3 \mathrm{~m}$.

According to this age model, the lowermost occurrence of $M$. trogontherii in the Vika layer has an extrapolated age of $\sim 0.8 \mathrm{Ma}$ and should fall within MIS 20 or at the MIS 20/MIS 19 termination, whereas the uppermost occurrence of $M$. trogontherii in the Nosak layer is dated to $0.19 \mathrm{Ma}$ in the early part of MIS 6 (Fig. 6). The large stratigraphic gap between site KF and KC and the general lack of chronologic control points in the lower part of the Kostolac composite section (apart from the Brunhes-Matuyama boundary) makes it difficult to estimate the age of onset of loess deposition recorded in site KF, which presumably falls in the MIS 12-MIS 16 range (Fig. 6).

\section{Discussion and conclusions}

Although the dispersal of $M$. trogontherii from Asia into Europe is generally accepted to have occurred sometime before the BrunhesMatuyama boundary (e.g., Lister et al., 2005; Palombo and Ferretti, 2005; Kahlke, 2014), there are in fact very few stratigraphic sections in Europe with remains of $M$. trogontherii that have reliable preBrunhes ( $>0.78 \mathrm{Ma}$ ) ages. Disregarding the molar fragment of M. trogontherii from Kärlich in Germany of insecure stratigraphic provenance (Lister et al., 2005), as well as the Kolkotova Balka site near Odessa at the gates of Europe for which we could not access and evaluate the original paleomagnetic data (Dodonov et al., 2006 and references therein), the only remaining European site that yielded $M$. trogontherii remains (molars) from levels that pre-date the Brunhes-Matuyama boundary is Dorn-Dürkheim 3 in Germany (Franzen et al., 2000; see also Lister et al., 2005; Kahlke, 2014). In this respect, the Kostolac sedimentary record appears to boast the remarkable characteristic of preserving in a continuous stratigraphy both the earliest occurrence in Europe of $M$. trogontherii at $\sim 0.8 \mathrm{Ma}$ in the latest Matuyama (Vika) and its last occurrence at $0.19 \mathrm{Ma}$ at the onset of MIS 6 (Nosak), probably later than the commonly accepted last occurrence at $~ 0.2$ Ma during MIS 7 (Lister and Sher, 2001; Lister et al., 2005).

M. trogontherii seems to have immigrated to Europe from Asia at broadly the same time (within a climatic cycle of typically $100 \mathrm{kyr}$ ) as Elephas antiquus came from Africa. The oldest remains in Europe of $E$. antiquus have been reported in the Torrent de Vallparadís section of northeastern Spain in levels of unit EVT7 (Martínez et al., 2010, 2014). Unit EVT7 yielded reverse magnetic polarity between the top of the Jaramillo (0.99 Ma) and the base of the Brunhes (0.78 Ma) (Madurell-Malapeira et al., 2010; see also MadurellMalapeira et al., 2012 and Garcia et al., 2012), and is associated with an average age of $0.83 \mathrm{Ma}$ based on ESR-U/series dating of two equine molars and OSL dating of four quartz grain samples (Martínez et al., 2010, 2014). This is virtually the same age as the weighted mean ESR age of $0.86 \mathrm{Ma}$ obtained on quartz grains from level EVT7 (Duval et al., in press). Older age estimates of $\sim 0.9 \mathrm{Ma}$ based on micromammal analyses have been recently questioned by Martin (2014) and Muttoni et al. (2015).

In the Guadix-Baza basin of southeastern Spain, the 30-m-thick Puerto Lobo section yielded a record of the Brunhes-Matuyama boundary (Gibert et al., 2007). The Huéscar-1 paleontological site with remains of E. antiquus (Gibert et al., 2007, table 1 and references therein; but see Lister, 2004), was traced $~ 10$ m below the BrunhesMatuyama boundary and presumably above the Jaramillo, which was not found in the section. 


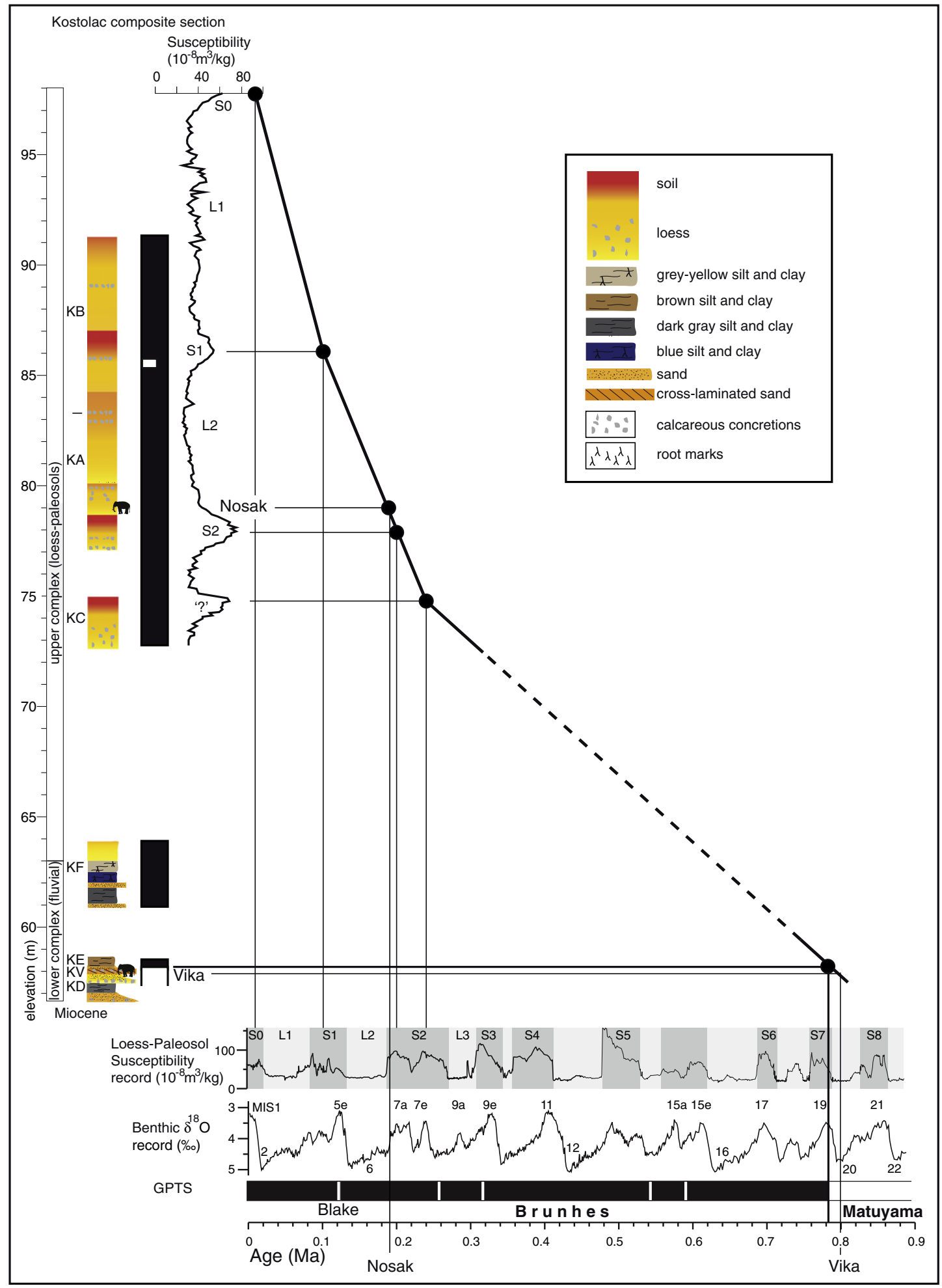

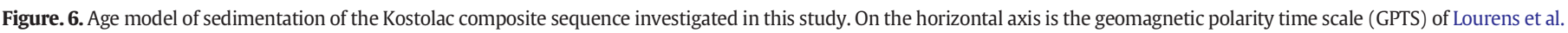

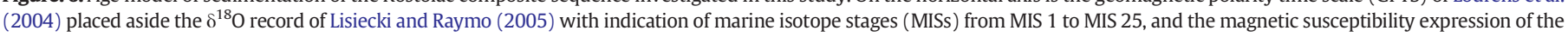

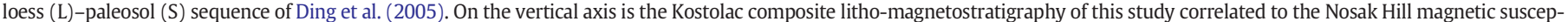

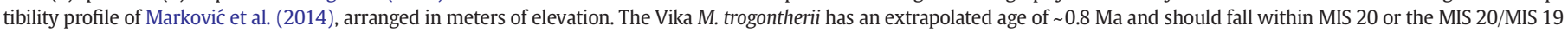
termination. The Nosak M. trogontherii is dated to 0.19 Ma in the earliest part of MIS 6. See text for discussion.

Muttoni et al. (2014) speculated that megaherbivores such as M. trogontherii and E. antiquus may have been 'pushed-and-pulled' into Europe in response to changes in African and southern European climate at the inception of higher amplitude glacial oscillations of the EPR centered on MIS $22(\sim 0.9 \mathrm{Ma})$ in the Late Matuyama.
Megaherbivore expansion apparently occurred on stable lowlands developed as the Po and Danube deltas prograded into the Adriatic Sea and Black Sea, respectively, during the EPR (Muttoni et al., 2014 and references therein) (Fig. 7). Colonization of these lowlands by grassland vegetation with reduced woody cover, especially during the onset of 


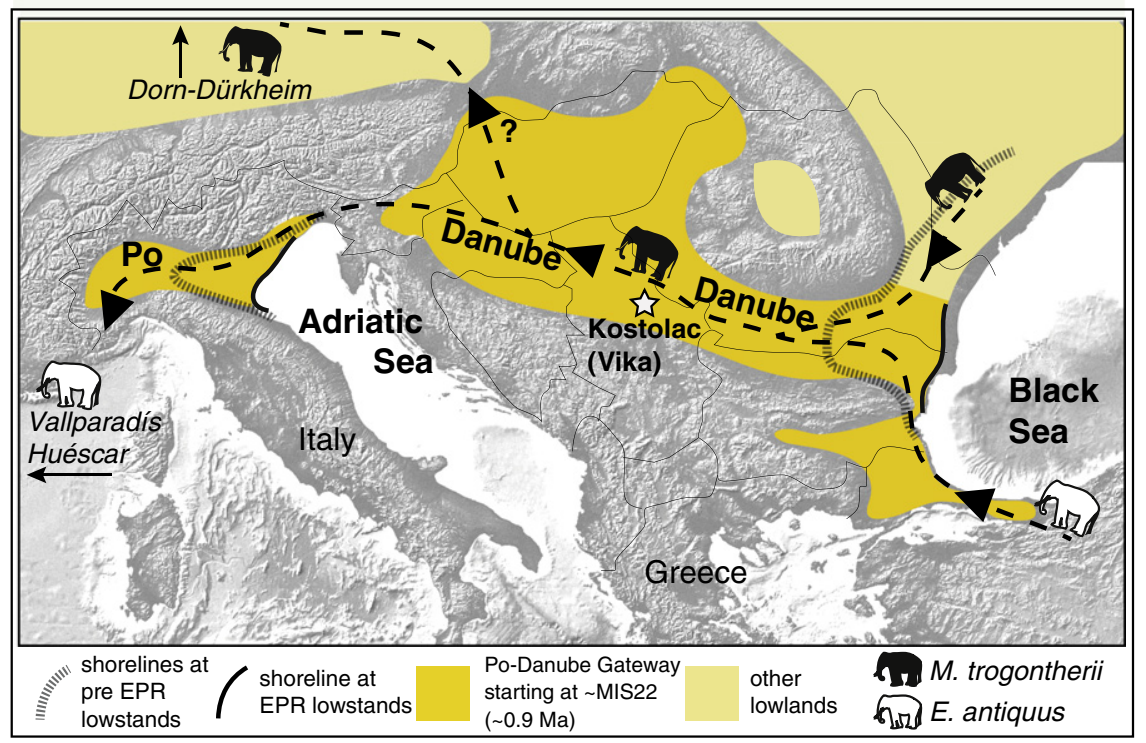

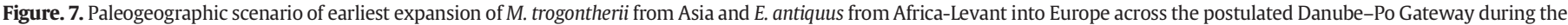

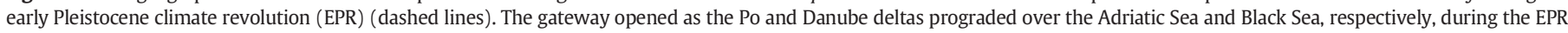

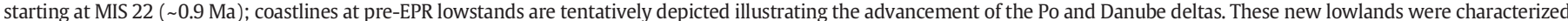

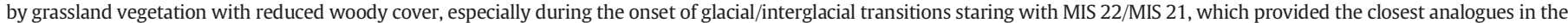
temperate belt of the savanna ecosystems to which migrant megaherbivores (e.g., M. trogontherii and E. antiquus) were adapted. Redrawn from Muttoni et al. (2014).

glacial/interglacial transitions starting with MIS 22/MIS 21, provided the closest analogues in the temperate belt of the savanna-type ecosystems to which migrant megaherbivores such as the Asian steppe mammoth (M. trogontherii) and the straight-tusked elephant (E. antiquus), derived from the African savanna elephant (E. recki), were well adapted (Cerling et al., 2011), and into which they expanded only since $\sim 0.9$ Ma, possibly together with hominins interlinked in a common food web. Before MIS 22, these lowlands, smaller in extent (see pre-EPR coastlines in Fig. 7), were covered by more permanent closed forests, considered as less suitable to migrant African and Asian megaherbivores. Our findings hence support a model (Muttoni et al., 2014) wherein the stratigraphic level with Vika (M. trogontherii) at Kostolac rests upon a regional horizon marking the EPR in the Danube Valley, similar to the ' $\mathrm{R}$ surface' in the Po Valley also dated at $\sim 0.9 \mathrm{Ma}$ (Muttoni et al., 2003; Scardia et al., 2010, 2012).

The regional horizon marking the onset of loess deposition during the EPR could represent a prime target for surveys in search of sites in the Danube area with mammal immigrants from Asia and Africa, possibly including early hominins. Whether or not hominins arrived in Europe before the EPR (e.g., Carbonell et al., 2008; Toro-Moyano et al., 2013) remains a matter of debate (Muttoni et al., 2013, 2015), but we find it intriguing that the close association of large herbivores such as elephants and lithic artifacts, as revealed by the (still meager) fossil record, can be traced back almost to the emergence of humankind in Africa (Gaudzinski et al., 2005).

\section{Acknowledgments}

The Senior Editor, the Associate Editor, and three anonymous reviewers are thanked for insightful comments. Christopher Lepre is thanked for comments on an earlier version of this manuscript. The Rector of the University of Milan is thanked for financial support to GM (grant \#14-22-3020000-307). The Ministry of Education and Science of the Republic of Serbia is thanked for funding project III 47001 'Bioarchaeology of Ancient Europe-Humans, Animals and Plants in the Prehistory of Serbia'. Lamont-Doherty Earth Observatory contribution \#7933.

\section{References}

Carbonell, E., de Castro, J.M.B., Parés, J.M., Pérez-González, A., Cuenca-Bescós, G., Ollé, A., Mosquera, M., Huguet, R., van der Made, J., Rosas, A., 2008. The first hominin of Europe. Nature 452, 465-469.

Cerling, T.E., Wynn, J.G., Andanje, S.A., Bird, M.I., Korir, D.K., Levin, N.E., Mace, W., Macharia, A.N., Quade, J., Remien, C.H., 2011. Woody cover and hominin environments in the past 6 million years. Nature 476, 51-56.

Dimitrijević, V., Mrdjić, N., Korać, M., Chu, S., Kostić, D., Jovičić, M., Blackwell, B.A., 2015 The latest steppe mammoths (Mammuthus trogontherii (Pohlig)) and associated fauna on the Late Middle Pleistocene steppe at Nosak, Kostolac Basin, Northeastern Serbia. Quaternary International 379, 14-27.

Ding, Z.L., Derbyshire, E., Yang, S.L., Sun, J.M., Liu, T.S., 2005. Stepwise expansion of desert environment across northern China in the past $3.5 \mathrm{Ma}$ and implications for monsoon evolution. Earth and Planetary Science Letters 237, 45-55.

Dodonov, A.E., Zhou, L.P., Markova, A.K., Tchepalyga, A.L., Trubikhin, V.M., Aleksandrovski, A.L., Simakova, A.N., 2006. Middle-Upper Pleistocene bio-climatic and magnetic records of the Northern Black Sea Coastal Area. Quaternary International 149, 44-54.

Duval, M., Bahain, J.-J., Falguères, C., Garcia, J., Guilarte, V., Grün, R., Martínez, K., Moreno, D., Shao, Q. Voinchet, P., 2014. Revisiting the ESR chronology of the Early Pleistocene hominin occupation at Vallparadís (Barcelona, Spain). Quaternary International. http://dx.doi.org/10.1016/j.quaint.2014.08.054 (in press).

Fitzsimmons, K.E., Marković, S.B., Hambach, U., 2012. Pleistocene environmental dynamics recorded in the loess of the middle and lower Danube basin. Quaternary Science Reviews 41, 104-118.

Franzen, J.L., Gliozzi, E., Jellinek, T., Scholger, R., Weidenfeller, M., 2000. Die spätaltpleistozäne Fossillagerstätte Dorn-Dürkheim 3 und ihre Bedeutung für die Rekonstruktion der Entwicklung des rheinischen Flußsystems. Senckenbergiana Lethaea 80, 305-353.

Garcia, J., Martínez, K., Carbonell, E., Agustí, J., Burjachs, F., 2012. Defending the early human occupation of Vallparadís (Barcelona, Iberian Peninsula): a reply to Madurell-Malapeira et al. (2012). Journal of Human Evolution 63, 568-575.

Gaudzinski, S., Turner, E., Anzidei, A., Àlvarez-Fernández, E., Arroyo-Cabrales, J., CinqMars, J., Dobosi, V., Hannus, A., Johnson, E., Münzel, S., 2005. The use of Proboscidean remains in every-day Palaeolithic life. Quaternary International 126, 179-194.

Gibert, L., Scott, G., Martin, R., Gibert, J., 2007. The Early to Middle Pleistocene boundary in the Baza Basin (Spain). Quaternary Science Reviews 26, 2067-2089.

Kahlke, R.-D., 2014. The origin of Eurasian Mammoth Fauna (Mammuthus-Coelodonta Faunal Complex). Quaternary Science Reviews 96, 32-49.

Lisiecki, L.E., Raymo, M.E., 2005. A Pliocene-Pleistocene stack of 57 globally distributed benthic ${ }^{18} \mathrm{O}$ records. Paleoceanography 20 , PA1003.

Lister, A.M., 2004. Chapter IV Ecological Interactions of Elephantids in Pleistocene Eurasia: Palaeoloxodon and Mammuthus. In: Goren-Inbar, N., Speth, J.D. (Eds.), Human Paleoecology in the Levantine Corridor. Oxbow Books, Park End Piace, Oxford, pp. 53-60.

Lister, A.M., Sher, A.V., 2001. The origin and evolution of the woolly mammoth. Science 294, 1094-1097.

Lister, A.M., Sher, A.V., van Essen, H., Wei, G., 2005. The pattern and process of mammoth evolution in Eurasia. Quaternary International 126-128, 49-64. 
Lister, A.M., Dimitrijević, V., Marković, Z., Knežević, S., Mol, D., 2012. A skeleton of 'steppe' mammoth (Mammuthus trogontherii (Pohlig)) from Drmno, near Kostolac, Serbia. Quaternary International 276, 129-144.

Lourens, L., Hilgen, F., Shackleton, N.J., Laskar, J., Wilson, D., 2004. The Neogene Period. In: Gradstein, F., Ogg, J., Smith, A.G. (Eds.), Geologic Time Scale. Cambridge University Press, Cambridge.

Madurell-Malapeira, J., Minwer-Barakat, R., Alba, D., Garcés, M., Gómez, M., AurellGarrido, J., Ros-Montoya, S., Moyà-Solà, S., Berástegui, X., 2010. The Vallparadís section (Terrassa, Iberian Peninsula) and the latest Villafranchian faunas of Europe. Quaternary Science Reviews 29, 3972-3982.

Madurell-Malapeira, J., Alba, D.M., Minwer-Barakat, R., Aurell-Garrido, J., Moyà-Solà, S. 2012. Early human dispersals into the Iberian Peninsula: a comment on Martínez et al. (2010) and Garcia et al. (2011). Journal of Human Evolution 62, 169-173.

Marković, S.B., Hambach, U., Stevens, T., Kukla, G.J., Heller, F., McCoy, W.D., Oches, E.A Buggle, B., Zöller, L., 2011. The last million years recorded at the Stari Slankamen (Northern Serbia) loess-palaeosol sequence: revised chronostratigraphy and longterm environmental trends. Quaternary Science Reviews 30, 1142-1154.

Marković, S.B., Hambach, U., Stevens, T., Jovanović, M., O'Hara-Dhand, K., Basarin, B., Lu, H., Smalley, I., Buggle, B., Zech, M., 2012. Loess in the Vojvodina region (Northern Serbia): an essential link between European and Asian Pleistocene environments. Netherlands Journal of Geosciences 91, 173-188.

Marković, S.B., Korać, M., Mrđić, N., Buylaert, J.P., Thiel, C., McLaren, S.J., Stevens, T., Tomić, N., Petić, N., Jovanović, M., Vasiljević, Dj.A., Sümegi, P., Gavrilov, M.B., Obreht, I., 2014 Palaeoenvironment and geoconservation of mammoths from the Nosak loesspalaeosol sequence (Drmno, northeastern Serbia): initial results and perspectives. Quaternary International 334-335, 30-39.

Martin, R.A., 2014. A critique of vole clocks. Quaternary Science Reviews 94, 1-6.

Martínez, K., Garcia, J., Carbonell, E., Agustí, J., Bahain, J.-J., Blain, H.-A., Burjachs, F., Cáceres, I., Duval, M., Falguères, C., 2010. A new lower Pleistocene archeological site in Europe (Vallparadís, Barcelona, Spain). Proceedings of the National Academy of Sciences 107, $5762-5767$.

Martínez, K., Garcia, J., Burjachs, F., Yll, R., Carbonell, E., 2014. Early human occupation of Iberia: the chronological and palaeoclimatic inferences from Vallparadís (Barcelona, Spain). Quaternary Science Reviews 85, 136-146.

Muttoni, G., Carcano, C., Garzanti, E., Ghielmi, M., Piccin, A., Pini, R., Rogledi, S., Sciunnach, D., 2003. Onset of major Pleistocene glaciations in the Alps. Geology 31, 989-992.
Muttoni, G., Scardia, G., Kent, D.V., 2013. Comment on 'The oldest human fossil in Europe from Orce (Spain)' by Toro-Moyano et al. (2013). Journal of Human Evolution 65, 746-749.

Muttoni, G., Kent, D.V., Scardia, G., Monesi, E., 2014. Migration of hominins with megaherbivores into Europe via the Danube-Po Gateway in the Late Matuyama Climate Revolution. Rivista Italiana di Paleontologia e Stratigrafia 120, 351-365.

Muttoni, G., Kent, D.V., Scardia, G., Martin, R.A., 2015. Bottleneck at Jaramillo for human migration to Iberia and the rest of Europe? Journal of Human Evolution 80, 187-190.

Palombo, M.R., Ferretti, M.P., 2005. Elephant fossil record from Italy: knowledge, problems, and perspectives. Quaternary International 126-128, 107-136.

Sartori, M., Heller, F., Forster, T., Borkovec, M., Hammann, J., Vincent, E., 1999. Magnetic properties of loess grain size fractions from the section at Paks (Hungary). Physics of the Earth and Planetary Interiors 116, 53-64

Scardia, G., Muttoni, G., Sciunnach, D., 2006. Subsurface magnetostratigraphy of Pleistocene sediments from the Po Plain (Italy): constraints on rates of sedimentation and rock uplift. Geological Society of America Bulletin 118, 1299-1312.

Scardia, G., Donegana, M., Muttoni, G., Ravazzi, C., Vezzoli, G., 2010. Late Matuyama climate forcing on sedimentation at the margin of the southern Alps (Italy). Quaternary Science Reviews 29, 832-846.

Scardia, G., De Franco, R., Muttoni, G., Rogledi, S., Caielli, G., Carcano, C., Sciunnach, D., Piccin, A., 2012. Stratigraphic evidence of a Middle Pleistocene climate driven flexural uplift in the Alps. Tectonics 31, TC6004.

Singer, B.S., 2014. A Quaternary geomagnetic instability time scale. Quaternary Geochronology 21, 29-52.

Thiel, C., Horváth, E., Frechen, M., 2014. Revisiting the loess/palaeosol sequence in Paks, Hungary: a post-IR IRSL based chronology for the 'Young Loess Series'. Quaternary International 319, 88-98.

Thouveny, N., Bourlès, D.L., Saracco, G., Carcaillet, J.T., Bassinot, F.C., 2008. Paleoclimatic context of geomagnetic dipole lows and excursions in the Brunhes, clue for an orbital influence on the geodynamo? Earth and Planetary Science Letters 275, 269-284.

Toro-Moyano, I., Martínez-Navarro, B., Agustí, J., Souday, C., Bermúdez de Castro, J.M., Martinón-Torres, M., Fajardo, B., Duval, M., Falguères, C., Oms, O., 2013. The oldest human fossil in Europe, from Orce (Spain). Journal of Human Evolution 65, 1-9. 